\title{
The strategic positioning of Australian research universities in the East Asian region
}

\author{
Simon Marginson \\ Professor of International Higher Education \\ Institute of Education, London, UK \\ Honorary Professorial Fellow \\ University of Melbourne, Australia \\ 20 Bedford Way \\ London WC1H 0AL \\ United Kingdom \\ + 447876323949 (mobile) \\ s.marginson@ioe.ac.uk
}

Bio. Simon Marginson is Professor of International Higher Education at the Institute of Education, London. He was Professor of Higher Education at the University of Melbourne in Australia from 2006-2013 and is an Honorary Professorial Fellow at that University. He is Joint Editor-in-Chief of Higher Education and a member of Academia Europaea.

\begin{abstract}
Regional tendencies in higher education are increasingly important, for example the common rise of North East Asian universities in China, Hong Kong SAR, Taiwan and South Korea, and Singapore in South East Asia, to a major global role, following the prior trajectory of Japan. Though the rapidly modernizing Post-Confucian countries do not constitute a formal region they share a common political and cultural dynamism, entailing rapid improvement of quantity and quality in education and research. This poses challenges and opportunities for Australia, a British/European heritage nation located at the edge of Asia, with extensive trade into East Asia, and an Asian-influenced demography, providing that it can (1) further develop its research capacity, given that research provides the main medium of deep collaboration in higher education, and (2) lift its cultural capacity to interface with systems in the region.
\end{abstract}

Keywords. Globalization, Australia, East Asia, Confucian heritage, Research, Innovation systems

\section{Introduction}


Higher education, and especially research science, are increasingly globalized (King, Marginson and Naidoo, 2011). Amid the thickening of cross-border relations the regional factor is becoming more important, as illustrated by the Bologna process and European Research Area, and cooperation in South America and through the Association of South East Asia Nations (ASEAN) in Asia. There are also informal regional developments in culturally conjoint nations, for example those that share common traditions or language.

Not all national systems are part of a regional grouping. Nations have varying positional options, determined by history, geography and cultural factors. This article explores the position and positioning of Australia, especially in relation to the dramatic evolution of higher education and science in East Asia and Singapore, geographically adjacent to Australia. In 2013 the question of Australia's positioning in Asia, and of the role of higher education and research in relation to Asia, became an issue of front rank policy importance in Australia, following an Australian government task force report.

\section{Australia and Australian universities}

Australia is a nation of 23.1 million people (ABS, 2013a) occupying an island continent off Southeast end of Asia in the Southern Hemisphere. It was founded as a British settlerstate that appropriated the land of the indigenous inhabitants. Like the North American countries it is a federation based on the unification of originally separated colonial enclaves. Australia achieved national independence in 1901.

Geographically Australia is positioned on the opposite side of the world to the United Kingdom (UK) and Europe, and it is economically shaped by its location close to Southeast and East Asia, a region of exceptional economic and social dynamism. The majority of Australia's trade is with China, Korea, Japan, Taiwan and Singapore. The 2011 census found the Asian-born share of the population had reached 10 per cent (ABS, 2013b). Table 1 indicates the reason pattern of newly arrived permanent migrants by country of origin. India and China are now two of the three largest sources of migrants.

\section{[Table 1 about here]}


Through migration Australia also has large sub-populations of Southern and Eastern European heritage. Nevertheless, it retains the British monarch as the nominal head of state, its flag includes the imperial British ensign, and it continues to be patterned by British norms in government, and policy, business, the professions, higher education and science. Perhaps Australia will have a happier future if it successfully combines its British/European history with its Asian location, but there are tensions; and as a British cultural formation, Australia's inherited common identity is linguistically and culturally singular. It needs to develop more resources with which to manage multiple identity.

\section{Higher education}

Australian higher education was patterned along English and Scottish lines and continues to closely resemble the UK sector, from the Treasury-driven polity and broad policy framework, to cultures of academic work, faculty promotion and the doctorate. In 2011 there were 1.2 million students in higher education, in institutions offering degree programs of at least three years in duration (DIICCSRTE, 2013), and a larger number of students in sub-degree programs in Vocational Education and Training (VET). The 36 public universities on the federal government's schedule, plus three private universities partly regulated and funded by government, dominate higher education, enrolling more than 90 per cent of students. All offer programs at doctoral level and nearly all offer a comprehensive suite of professional degrees, though there is much variation in research intensity. On average the 36 universities receive just over 40 per cent of their income from government sources, with almost 40 per cent constituted by fees and charges. In 2010 public expenditure on all tertiary education was 0.8 per cent of GDP, below the OECD average of 1.1 per cent. Private expenditure is relatively high at 0.9 per cent (OECD, 2013 , p. 193). Tuition is also high but supported by a system of tuition loans based on income contingent repayments, which minimizes price-based disincentives to enrol.

The Gross Tertiary Enrolment Ratio (GTER) was 86.3 per cent in 2012 (UNESCO, 2014), though this is boosted by international students, and includes persons who do not complete programs. More than one third of local 25-34 year olds achieve degree level qualifications. First and second generation migrant families, particularly from China and Vietnam, are over-represented in university education relative to their population share. The OECD's Education at a Glance 2013 notes that in 2011, 20.8 per cent of students 
enrolled in Australia in degree granting institutions had crossed the national border for education, the highest proportion of any OECD nation (OECD, 2013, p. 317). Perhaps one third of international students become permanent residents after graduation, constituting part of the skilled migration intake. Four fifths of Australia's international students are from Asia. The largest source countries are China, India and Vietnam. Students from Korea are well represented in 6-12 months English-language teaching programs.

Apart from a small number of scholarships for doctoral students, international education is run on a commercial basis, and in 2011 generated 17.5 per cent of the revenue of higher education institutions (DIICCSRTE, 2013). International education at all levels is Australia's fourth largest export industry after coal, iron ore and goal, ahead of tourism and all agricultural sectors. International students in higher education tend to be concentrated in first degree and Masters programs in business and technologies.

\section{Research}

On the global scale research activity in Australia is stronger in breadth than depth. In 2014 there were 19 Australian institutions in the Shanghai Academic Ranking of World Universities top 500 universities, an excellent spread of capacity for a nation of this size. However, the highest placed Australian institution in ARWU in 2014 was the University of Melbourne at 44, whereas Australia's closest comparator Canada had two universities in the world top 40. There were eight Australian institutions in the top 200 (ARWU, 2014).

In a Thomson-ISI summary of aggregate citations for 2001-2011-including research papers from government research laboratories, and private companies, as well as universities-Australia was $10^{\text {th }}$ nation on volume of citations but $17^{\text {th }}$ on average citations per paper. The rate of citation was above the West European average in five disciplinary areas: veterinary science, energy, engineering, earth and planetary science and medicine. In most fields of research the citation rate was between the West European and world averages. In the UK all fields of research were above the West European average (Chubb, 2013). While Australia's per capita income is higher than the UK and most of Western Europe its citation rates lag behind.

\section{Australian government focus on Asia}


For over 25 years Australian government has encouraged the export of educational services in Asia. The principal motive has been export revenue, but one policy rationale is to build relations between Australia and its Asian neighbours. However, successive Australian governments were reluctant to position Australian universities-and their research, not just their educational exports-in the context of national strategy in Asia. This changed with the Prime Minister-appointed Task Force on Australia in the Asian Century, led by former Secretary to the Treasury Ken Henry. The White Paper on Australia in the Asian Century, completed in October 2012, argued that Australian engagement with Northeast, Southeast and South Asia was of front tank importance:

Asia's rise is changing the world... The scale and pace of the change still to come mean Australia is entering a truly transformative period in our history... An wealthier and more mobile middle class is emerging in the region, creating new opportunities. They are demanding a diverse range of goods and services, from health and aged care to education to household goods, and tourism, banking and financial services, as well as high-quality food products. Beyond economic gains, there are many valuable opportunities for building stronger relationships across the region, including through closer educational, cultural and people-to-people links (Australian Government, 2012, p. 1).

The Task Force report argued for multi-sectoral engagement. Higher education and science were among the most important mediums for Australia-Asia relations:

A growing proportion of global scientific research is taking place in Asia. Partnerships with research and technology communities are crucial to supporting Australia's ability to access new ideas and to build our future competitiveness (Australian Government, 2012, p. 266).

Higher education in Australia is more extensively engaged in the region than most Australian sectors, especially in Singapore, Hong Kong SAR, Malaysia, Japan, China and Vietnam. Australian institutions have branch campuses in Malaysia, Singapore, Hong Kong SAR and China. Nevertheless, higher education is not yet fully equipped for the challenge laid down by the government Task Force. The primary orientation is the 
recruitment of fee-paying students. In research Australian universities connect better with North America and the UK than Asia, aside from Singapore (NSF, 2014). The Australian National University (ANU) has specialized in Asia-Pacific studies since its foundation, but outside ANU few university leaders and professors are fluent in any Asian language. A small minority of students pursue in-depth studies of Asian economy, society, history, politics, language or culture. Some in Australian universities, as in business and government, still see themselves as the British in Asia, or think that they have a choice about whether to engage regionally. These stances position Australia poorly in Asia.

The question of Australia's strategic positioning has become more urgent in the light of the remarkable evolution of education and research in East Asia and Singapore.

\section{The global and regional setting}

The last two decades have seen a great worldwide expansion in the social and economic reach of higher education and research science, associated with communicative globalization and networking (Marginson, 2011a), knowledge-intensive work and technological innovations, urbanization, and the expansion of the middle class. The capitalist economy is absorbing pre-capitalist rural sectors in Asia, Africa and Latin America. Cities now house more than 50 per cent of the world's population. The Brookings Institute estimates the global middle classes, persons with \$10-100 USD a day, will grow from 1.8 to 4.9 billion between 2009 and 2030, with 3.2 billion in Asia (Kharas and Gertz, 2010, p. 6). Middle class families want higher education for their children.

\section{[Table 2 about here]}

From 2000 to 2012 the GTER in East Asia and the Pacific rose from 16 to 31 per cent (UNESCO, 2014). Research science has also spread. All nations now need capability in education, science and technology — though not all can pay for it—just as they need clean water, stable governance and globally viable finance. They need universities that can participate in global knowledge networks. Nations and cities without the capacity to interpret and understand research, a capacity that rests on trained personnel capable of creating research, are locked into continued dependence. The growth of research is sustained by collaborations and the globalization of knowledge within one-world English 
language science. It also takes the competitive form of an economic arms race in R\&D and innovation, in which university rankings signify the competitive position, and emerging systems are rapidly increasing science paper output. Between 1995 and 2011 the output of scientific journal papers from Asia multiplied by almost three times (NSF, 2014).

Capacity in higher education and science is pluralizing. In 2010, 50 countries published over one thousand science papers (Table 2), a proxy measure for a system with indigenous scientific capacity in at least some disciplines, compared to 38 countries in 1995 (NSF, 2014). China, Hong Kong SAR, Taiwan and Korea in East Asia, and Singapore in Southeast Asia, have joined Japan as high participation high science education and research systems. These 'Post-Confucian' systems (Marginson, 2011b), exhibit a common dynamism. They combine traditions from Chinese (Sinic) civilization with rapid modernization in the economy, government, education and science, rooted in the encounter with the West. Hence the term 'post-Confucian'1. Unlike Europe, higher education in East Asia is not moving on the basis of regulated regional cooperation, but it is moving in parallel. The Post-Confucian system nations differ in language, social habits and political arrangements, and there are political tensions between them. Nevertheless, they have common features that have facilitated their shared upward trajectory, as is explored further below. First, however, rising East Asia will be explored empirically.

\section{Higher education and research in the post-Confucian systems}

\section{Participation in tertiary education}

All Post-Confucian systems are heading towards universal participation. In 2011 the GTER exceeded 85 per cent in South Korea and Taiwan. Macau SAR was at 65 per cent and Japan and Hong Kong SAR 60 per cent. Hong Kong and Singapore have moved from the non-universal systems inherited from Britain primarily by building sub-degree numbers. In China the GTER moved from 5 per cent to 27 per cent between 1990 and 2012 (UNESCO, 2014). The 2020 target is 40 per cent. Institutional quality varies. The top 200 universities have been lifted; the challenge is to improve other institutions and lift participation in the poorer provinces. But the Post-Confucian systems largely avoid tradeoffs between advances in quality and in quantity. Both are occurring simultaneously. 
Government and households share the cost of participation, enabling the state to focus part of its funding on elite national research universities, their students and (in some systems) social equity. A feature of Post-Confucian systems-in marked contrast to Europe-is that poor families often invest heavily in schooling, extra tutoring and classes. Post-Confucian families can spend as much on education as Australians spend on housing.

\section{[Table 3 about here]}

In Korea in 2010, 72.7 per cent of the cost of tertiary institutions was paid privately including 47.1 per cent by households, with 27.3 per cent financed by government. In Japan the private share was 65.6 per cent (OECD, 2013, p. 207), in China about 40 per cent. Levin (2011) finds Koreans spend 3 per cent of GDP on non formal schooling, including extra classes after school and private tutoring. Public and private investment, and state reform of schooling, combined with parental focus on student achievement and the pressure of examinations, prepares students for tertiary education at an advanced level (Table 3). The 2012 OECD Program of International Student Assessment (PISA) found that the top seven systems in the world in mathematics were Shanghai (613), Singapore (571), Hong Kong SAR (561), Taiwan (560), South Korea (546), Macau (538) and Japan (536). Post-Confucian systems performed almost as well in science with six of the top eight systems, and reading with six of the top seven systems (OECD, 2014). The school systems of East Asia and Singapore not only have high average achievement, and large groups of high achievers, they have small groups of low achievers. Again there is no necessary tradeoff between quantity and quality, or between equity and excellence.

\section{[Figure 1 about here]}

Research science

Post-Confucian investment in R\&D as a proportion of GDP is on par with Western Europe. South Korea invested 4.03 per cent of GDP in 2011, and Taiwan 3.02 per cent compared with 3.78 per cent in Finland, 2.85 per cent United States and 2.20 per cent in Australia. China's investment was 1.84 per cent of GDP (NSF, 2014) and was increasing by 0.1 per cent a year. The national target is 2.5 per cent by 2020 . If spending continues to grow at 
this rate China's R\&D will pass the USA in the next five years. As in South Korea, a relatively low proportion goes to universities, less than one yuan in ten, but the universities also partner the state enterprises that conduct most R\&D in China. PostConfucian Asia spends much more on R\&D than Western Europe including the UK. In 2009 North America invested $\$ 451$ billion in R\&D, Western Europe \$320 billion and PostConfucian Asia $\$ 448$ billion, a third of the global total (NSF, 2014).

Figure 1 shows that three of the world's five largest R\&D investor nations are postConfucian: China, Japan and South Korea. Taiwan is in the top ten (NSF, 2014). In constant price terms China's R\&D multiplied by five times between 2000 and 2011. Post-Confucian research systems are strongly biased to applied research and commercialization, with basic university research less well supported than in the United States or Western Europe. Nevertheless, with all research budgets rising, except in Japan, university research funding and scholarly output are growing vigorously.

Figure 2 lists the leading nations in journal paper output, drawing on ISI-Thomson Web of Knowledge data, which include economics, business, demography, psychology, and some social science plus the physical, life and applied sciences. In 2011 two of the three largest producers were Post-Confucian systems. South Korea was $9^{\text {th }}$, three places ahead of Australia. Taiwan was $14^{\text {th }}$ (NSF, 2014). India was the only other Asian system.

\section{[Figure 2 about here]}

The advance of Chinese science has been extraordinary (Figure 3). In 1995 China was the world's twelfth largest producer of science papers. In 2011 it was second. Since 2000 annual output has grown by 16 per cent per year. When the world's largest nation expands research at unprecedented rates over a prolonged period, knowledge flows are changed. In future much of science will come from China. Science has grown almost as rapidly in South Korea, and increased sharply in Singapore and Taiwan (NSF, 2014).

Research is less dynamic in India but its growth has quickened in the last half decade. Of the other Asian systems Thailand produced 2304 papers in 2092, Malaysia 2033 and Pakistan 1268. The world's fourth most populous nation, Indonesia, produced only 270 papers. There were 291 in Bangladesh, 241 in the Philippines and 432 in Post-Confucian Vietnam, all nations with large populations but lacking indigenous science (NSF, 2014). 


\section{[Figure 3 about here]}

In the process of development research quantity moves ahead of research quality. In 2012 China produced 9.2 per cent of all science papers, but 5.8 per cent of papers in the top 1 per cent by citation rate. The US produced 26.6 per cent of papers but 46.4 per cent of the top 1 per cent papers. The patterns are uneven by discipline. The strengths of PostConfucian research are the physical science-based disciplines that underpin transport, communications, energy, urban construction and infrastructure. In engineering, chemistry, computer science, physics and mathematics, China's share of published research is relatively high and quality is improving rapidly. In engineering in 2012, China had 15.2 per cent of all papers and 12.2 per cent of the top 1 per cent. In Chemistry, in 2000 China had 0.6 per cent of the top 1 per cent papers. In 2012 it achieved 16.3 per cent of the leading papers, an astonishing improvement. However, in medicine and biological sciences China generated just 1-2 per cent of the top papers in 2012 (NSF, 2014).

Note that in Figure 3 Australia began in 1995 as the largest research producer after Japan. In 2009 it was fifth, behind China, Japan, South Korea and India.

\section{World-Class Universities}

Governments in East Asia and Singapore place a high priority on developing 'World-Class Universities' (WCUs), concentrations of status and research modeled originally on US and UK/Western European examples. WCU policy builds on pre-given national hierarchies, like the pre-World War Two Imperial universities in Japan; Peking University (1898) in China; and Seoul National University (1946) in Korea. There are also successful recent foundations, such as the Hong Kong University of Science and Technology, which opened in 1991 (Postiglione, 2011). WCUs are supported by special investment funding such as the 211 and 985 programs in China and Brain 21 in Korea (Shin, 2009).

It takes time for WCU investment to show in global rankings. There are lags between investment and published science, between publication and citation, and between citation and change in the rankings. China's investment is now achieving results. In the Shanghai Academic Ranking of World Universities (ARWU, 2014) the number of top 500 universities in mainland China increased from 8 in 2005 to 32 in 2014, with five more in Hong Kong SAR. In 2011 Tsinghua was the only top 200 university. In 2014 there were six 
top 200 universities and three-Tsinghua, Peking and Shanghai Jiao Tong-in the top 150. Current investments in R\&D will show in the rankings in 5-10 years. The full effects will take a generation or more. By 2030 the leading universities in China, South Korea, Taiwan and Singapore will be highly placed and there will be many more in the top 200 .

The Shanghai ranking also lists the top 100 institutions in five broad research fields. There are 30 Post-Confucian universities in the world top 100 in engineering. China and Taiwan between them have 21. Nanyang in Singapore is $12^{\text {th }}$ in the world and the Natioanl University of Singapore is $16^{\text {th }}$, while in China Tsinghua is placed $20^{\text {th }}$ and Harbin IT at $21^{\text {st }}$. Shanghai Jiao Tong is $27^{\text {th }}$. The City University of Hong Kong is 24 th in the world and Hong Kong University of Science and Technology 30th. National Taiwan University, a major player in computing research, is $26^{\text {th }}$. Australia has five engineering schools in the world top 100 but none in the top 40 (ARWU, 2014).

A more precise regional picture is provided by the Leiden University Centre for Science and Technology Studies (Leiden University, 2014). It ranks universities using separated single indicators, including volume of science papers, citations, cites per paper, and papers in the top 10 per cent of their field by citation rate. ${ }^{2}$ Table 4 lists the thirty leading Asia-Pacific universities, including Australian universities, by their number of top 10 per cent papers (second last column). The table also includes total papers in Web of Science, and the proportion of papers in the top 10 per cent of their field by citation rate. Despite the limits of citation counts as a measure of quality, including the omission of much of social science and all humanities, the second last column in Table 4 is a useful summary of the scientific firepower of a university-its 'quantity of quality' in research.

\section{[Table 4 about here]}

The two Singapore universities have high citation rates, above all the Australian universities, and close to the best Western European universities aside from Cambridge and Oxford. The National University of Singapore is also the sixth largest producer of science in the region. There are 12 mainland Chinese universities in the top thirty, plus two from Hong Kong. Tsinghua has a citation rate just below the leading Australian universities, a strong performance for a non-English speaking institution. There is an interesting group of smaller science specialists. The University of S\&T in China has an excellent citation rate, as does the Hong Kong UST and Postech in Korea, too small for the 
table. The leading universities in Japan have strong outputs but relatively low rates of top 10 per cent papers, aside from Tokyo. Of the world top 100 universities by proportion of papers in the top 10 per cent, 16 are in the Asia-Pacific, with Tokyo (29) and NUS in Singapore (30) placed in the first thirty (Leiden University, 2014).

\section{Dynamics of the Post-Confucian Model}

Beginning with Japan in the 1960s/1980s, followed by Taiwan, Korea and Singapore in the 1990s, and China in the last decade, the Post-Confucian systems have achieved three objectives simultaneously: rapid expansion of participation, rapid growth of research science, and world-class universities. No other system of higher education and university research has moved forward at this pace in all three; and the Post-Confucian systems have done it within low tax polities. In 2007 public spending as a share of GDP was less than 15 per cent in Hong Kong SAR, Japan and Taiwan, 19.3 per cent in China and 20.8 per cent in Korea (ADB, 2010), compared to over 50 per cent in parts of Europe.

The key elements in the upward trajectory of Post-Confucian higher education and science have been the comprehensive and active central Sinic state, Confucian educational practices in the home, effective internationalization strategies that have rapidly absorbed Western modernization in higher education and science, and economic growth sufficient to pay for educational infrastructure and research. All Post-Confucian countries except China and Vietnam now enjoy per capita incomes at West European levels.

Perhaps the Sinic state is better equipped than Western states for the accelerated upgrading of universities and R\&D in terms of scope and mission. The Sinic state form, which originated in China's Qin and Han dynasties in the third century BCE, followed a different path to the limited liberal state of John Locke and Adam Smith. In the Englishspeaking countries the right of the state to tax and intervene is habitually questioned. East Asians mostly accept the legitimacy of the state as supervisor of society and social conduct. Government as a vocation has higher standing than in English-speaking countries. Many of the best graduates from top universities enter state office, not the professions or business. Dissidents, as in Tiananmen in 1989, rarely rail against the legitimacy of the state as such. Rather they call on the state to discharge its responsibilities in a proper manner, to behave as a state should behave. 
In all East Asian systems government leadership is deemed indispensable for a smooth functioning of the domestic market economy and vital for enhancing national comparative advantage in international competition. The central government is expected to have a holistic vision of the well-being of the nation and a long-term plan to help people maintain an adequate livelihood .... Strong government with moral authority, a sort of ritualized symbolic power fully accepted by the overwhelming majority, is acclaimed as a blessing (Tu, 1996, p. 7).

In the home the Confucian commitment to self-cultivation via learning was first established on a mass basis in China in the Song dynasty a thousand years ago. Respect for education in East Asia and Singapore is more deeply rooted than in Europe and North America, where mass education dates from the nineteenth century. Education is part of the duty of child to parent and of parent to child, a source of virtue, social standing and meritocratic advance. The family and individual schooling are joined to social ordering by the 'one-off' examination systems that select students into the leading universities.

East Asian higher education has also been shaped by norms and models from Europe and the American research university, entrenched through effective internationalization programs (Wang, Wang \& Liu, 2011): the sponsored mobility of students and scholars and measures to attract back the diaspora; recruitment of foreign scholar-researchers; English language learning, incentives for global publishing in English, and English medium graduate studies and international education; benchmarking of universities and disciplines against counterparts in North America and Europe, and rankings to drive WCU ambitions; and New Public Management reform of organization. Since Meiji Japan catchup with the West has been the policy driver, though competition with other Asian nations is becoming important. The Post-Confucian systems of higher education and research are East-West hybrids. They are also something new: a distinctive Post-Confucian modernization. Western influence has not displaced educational or political tradition. The relation between tradition and modernity is one of exchange, not displacement. Much of the potency of the Post-Confucian Model of education derives from its indigenous elements: the Confucian tradition at home, and constructive state policy in society.

In sum, higher education in East Asia and Singapore is shaped by a distinctive cultural configuration that both coincides with, and diverges from, English-speaking nations such as Australia. East Asian universities understand the map of similarity and 
difference better than Australian universities. Post-Confucian higher education has had no choice but to understand the West. Table 5 summarizes the variations between PostConfucian, US and Westminster (including Australian) higher education:

[Table 5 about here]

\section{Australia and East Asia}

Can Australia find common cause with, and enhance cooperation with, the rising East Asian systems in higher education and research? What are the conditions and prospects? Can Australian higher education become part of a regional grouping? More generally, how might Australian universities enhance cooperation in rising East Asia?

\section{Conditions of regional identity}

In the global setting, regional formation in higher education (and other spheres) depends on four elements. First, systems must be sufficiently resourced to enable partnership rather than relations of dependency. Second, geographical proximity. Third, common cultural elements, as in Latin America. Fourth, political will. National education systems must want to regionalize, as with the Bologna accord in Europe. At this stage the PostConfucian countries fulfill the first three conditions but the political will is weak. The Association for South East Asian Nations (ASEAN) has the political will to develop regionally but with the exception of Singapore its higher education systems are underdeveloped, and there is less cultural commonality than in Post-Confucian Asia or Western Europe. Both Northeast and Southeast Asia have limited themselves to small-scale mobility schemes such as staff and student exchange between leading universities.

Inclusion of Australian higher education in a consciously regional Asian higher education is not in prospect. There is regional potential but no acknowledged regional identity to join with, Australia is on the geographical edge, there is no will to bring Australia in, and there is a cultural gulf between Australia and all regional systems, with the partial exception of former British Hong Kong and Singapore. The only potential for transformative Australian/Asian structures is in research (below). Australian integration into Asian higher education is a matter for bilateral negotiations between states and 
between institutions. Here the two crucial issues are the mutual research capacities of potential partners, and joint capacity for cultural understanding.

\section{Research capacity}

In future regional research standards will be set more by East Asian systems than Australia. Australian universities will need to add value at the top end to be effective. One key to lifting Australia's potential contribution in the region is to hasten the development of Australian research capacity. Government did this in 1957-1975 in Australia when modern mass higher education and university research were built. Currently there are political obstacles: small tax politics, and resistance to building selected global research universities. Australian institutions are enterprising but of one middling type. Even the Australian National University's special research funding, which long sustained its research in Asia and the Pacific, is being folded back into the one-size-fits-all approach characteristic of the system (Marginson and Marshman, 2013). This may have to change. Top tier institutions carry cross-country research relationships in higher education. The stronger those universities, the greater the scope for regional integration.

\section{[Table 6 about here]}

The Leiden University data confirm that the top Australian research universities are equivalent to the top regional universities, though a little behind Singapore in citation quality. There is also more to it than research capacity alone. While the leading Australian institutions have the firepower to partner in Asia, especially in medicine and other applied life science fields, what is it that they bring to potential partnerships, that is superior to UK, USA and Canada? Much depends on the willingness of Australian universities to tool themselves within the current resource envelope to collaborate better in Asia. This means making use of their geographical proximity to regional systems to also deepen the cultural interface. Otherwise they do not have enough to offer. In the longer term, the growing demographic weight and organizational role of East Asian heritage families in Australian universities may broaden the highway into the region.

What is the present pattern of collaboration? Table 6 shows that Australian research collaboration with Singapore is strong, and above the expected level in China and Taiwan, 
but relatively low in South Korea and Japan. Australian scientists collaborate with China (1.11) at about the same rate relative to average patterns than the USA (1.10). Though this is a good starting point intensive collaboration has yet to become established.

The Australian Chief Scientist's Office has suggested one structural initiative that could advance research collaboration: the formation of an 'Asian-Area Research Zone'.

To gain maximum benefit from our STEM investments in knowledge generation, we must link to the work of the international community... Many of the challenges that confront Australia are similar to those of our regional neighbours. There is now an opportunity to share talents, skills, expertise and infrastructure that arises rarely. Accordingly, it is proposed that Australia seek to enter into a partnership with neighbours to establish an Asian-Area Research Zone (Chubb, 2013, p. 18)

An Asia-Area Research Zone could be developed as a partnership-based research program similar to the European Research Area. Each participating country could provide a share of the total funding based on size and capacity to pay. Grants would be peerreviewed and awarded only to cross-country partners and teams. As noted there are barriers in Asian higher education and to the formal inclusion of Australia in regional arrangements. However, there is likely to be more support for inclusion of Australia in a cooperative research program than in other formal way, providing that Australian institutions also develop and sustain the cultural wherewithal to work in East Asia.

Australian universities will also need to understand the distinctive features of PostConfucian systems if they are to work and learn more effectively in the region. This is not solely a matter of language and historical knowledge. It is also a matter of power and relationships. More than education exports, research allows Australians to transcend the inherited neo-colonial British strategy, via partnerships based on genuine equality. This is central to Australia's positioning in the region, if mutual benefit is to flourish.

\section{Notes}

1 The author previously used the term 'Confucian Model' (Marginson, 2011b). However, 'Confucian' carries unintended meanings reflecting prior usage in terms of fixed cultural categories. Cultural identity in higher education in East Asia (like elsewhere) is not fixed, but continually evolving, and hybrid in character. 
2 The citation data are provided in both raw form and on a field-normalized basis, whereby the Leiden group adjusts the raw data to account for different rates of publication and citation in research fields. 


\section{References}

Academic Ranking of World Universities, ARWU (2014). Shanghai Jiao Tong University

Graduate School of Education. (http://www.shanghairanking.com/index.html

Asian Development Bank, ADB (2010). Key Indicators for Asia and the Pacific 2009. Manila: ADB.

Australian Bureau of Statistics, ABS (2013a). Population Clock, 7 July.

http://www.abs.gov.au/ausstats/abs@.nsf/0/1647509ef7e25faaca2568a900154b63?op endocument

Australian Bureau of Statistics, ABS (2013b). Reflecting a Nation: Stories from the 2011 Census, 2012-2013. ABS Catalogue Number 2071.0.

http://www.abs.gov.au/ausstats/abs@.nsf/Lookup/2071.0main+features902012-2013

Australian Government (2012). Australia in the Asian Century (the Henry report). http://www.asiaeducation.edu.au/verve/_resources/australia-in-the-asian-centurywhite-paper.pdf

Chubb, I. (2013). Science, Technology, Engineering and mathematics in the National Interest. Chief Scientists' Office, Australian Government.

http://www.chiefscientist.gov.au/wpcontent/uploads/STEMstrategy290713FINALweb.pdf

Department of Immigration and Border Protection, DIBP, Australia (2012). Net Overseas Migration. Canberra: DIBP.

Department of Industry, Innovation, Climate Change, Science, Research and Tertiary Education, DIICCSRTE (2013). Statistics Publications.

http://www.innovation.gov.au/HigherEducation/HigherEducationStatistics/StatisticsPu blications/Pages/default.aspx 
King, R., Marginson, S. and Naidoo, R. (eds.) (2011). Handbook of Higher Education and Globalization. Cheltenham: Edward Elgar.

Kharas, H. and Gertz ,G. (2010). The new global middle class: A cross-over from West to East. In C. Li (ed.), China's Emerging Middle Class: Beyond economic transformation. Washington: Brookings Institution Press.

Leiden University (2014). Centre for Science and Technology Studies, CWTS. The Leiden Ranking 2013. http://www.leidenranking.com/default.aspx

Levin, H. (2011). Teachers College, Columbia University. Conversation with the author. Melbourne, 26 September.

Marginson, S. (2011a). Imagining the global. In R. King, S. Marginson and R. Naidoo (eds.), Handbook of Higher Education and Globalization, pp. 10-39. Cheltenham: Edward Elgar.

Marginson, S. (2011b). Higher Education in East Asia and Singapore: Rise of the Confucian Model, Higher Education, 61 (5), pp. 587-611.

Marginson, S. and Marshman, I. (2013). System and structure. In G. Crowther, S. Marginson, A. Norton and J. Wells (eds.), The Dawkins Revolution 25 Years On, pp. 56-74. Melbourne: Melbourne University Publishing

National Science Foundation, NSF (2014). Science and Technology Indicators 2012. National Science Board. http://www.nsf.gov/statistics/seind12/

Organisation for Economic Cooperation and Development, OECD (2013). Education at a Glance 2011: OECD indicators. Paris: OECD.

Organization for Economic Cooperation and Development, OECD (2014). PISA 2012 Results in Focus. What 15 year olds know and what they can do with what they know. Paris: OECD 
Postiglione, G. (2011). The rise of research universities: The Hong Kong University of Science and Technology. In P. Altbach \& J. Salmi (eds.) (2011), The Road to Academic Excellence: The making of world-class research universities, pp. 63-100. Washington: The World Bank.

Shin, J. (2009). Building world-class research university: The Brain Korea 21 project. Higher Education, 58 (5), pp. 669-688.

Tu, Wei-Ming (1996). Introduction. In W.-M. Tu (ed.), Confucian Traditions in East Asian Modernity: Moral education and economic culture in Japan and the four mini-dragons. Cambridge: Harvard University Press.

UNESCO (2014). Institute for Statistics. Tertiary Indicators. http://stats.uis.unesco.org

Wang, Q., Wang, Q. \& Liu, N. (2011). Building world-class universities in China: Shanghai Jiao Tong University. In P. Altbach \& J. Salmi (eds.) (2011), The Road to Academic excellence: The making of world-class research universities, pp. 33-62. Washington: The World Bank. 
Table 1. Permanent migration to Australia in two principal categories, the four leading countries of origin, year ending September 2004 to year ending September 2012

\begin{tabular}{|c|c|c|c|c|c|c|c|c|c|}
\hline & 2004 & 2005 & 2006 & 2007 & 2008 & 2009 & 2010 & 2011 & 2012 \\
\hline \multicolumn{10}{|c|}{ SKILLED ENTRY } \\
\hline UK & 10,067 & 11,356 & 14,923 & 14,422 & 14,508 & 10,978 & 7919 & 6401 & 8763 \\
\hline China* & 3145 & 3242 & 3762 & 4524 & 5647 & 4898 & 4938 & 4703 & 5120 \\
\hline India & 4745 & 5193 & 6967 & 8096 & 9783 & 8693 & 6587 & 5093 & 5995 \\
\hline Philippines & 1642 & 1589 & 2128 & 2345 & 2560 & 2098 & 1831 & 1812 & 2342 \\
\hline \multicolumn{10}{|c|}{ FAMILY ENTRY } \\
\hline China & 3755 & 3669 & 3549 & 4441 & 4561 & 5374 & 5430 & 5528 & 5811 \\
\hline India & 1575 & 1818 & 2231 & 2694 & 3507 & 3696 & 3783 & 3349 & 3762 \\
\hline Philippines & 2190 & 2036 & 2265 & 2501 & 2746 & 2853 & 2676 & 2533 & 2980 \\
\hline UK & 3980 & 3552 & 3816 & 3649 & 3422 & 3585 & 3260 & 2860 & 2673 \\
\hline
\end{tabular}

* Excludes SARs

Source: DIBP, 2012, p. 86 and p. 94 
Table 2. Nations publishing more than one thousand science papers in 2011

\begin{tabular}{|c|c|c|c|c|c|}
\hline ANGLO-SPHERE & EUROPEAN UNION & NON-EU EUROPE & ASIA & $\begin{array}{l}\text { LATIN } \\
\text { AMERICA }\end{array}$ & MIDDLE EAST \\
\hline USA 212,394 & Germany 46,259 & Russia 14,151 & China 89,894 & Brazil 13,148 & Iran $8176^{*}$ \\
\hline UK 45,884 & France 31,686 & Switzerl'd 10,019 & Japan 47,106 & Mexico 4173 & Israel 6096 \\
\hline Canada 29,114 & Italy 26,503 & Turkey 8328 & Sth. Korea 25,593 & Argentina 3863 & S. Arabia $1491^{*}$ \\
\hline Australia 20,603 & Spain 22,910 & Norway 4777 & India 22,481 & Chile 1979* & \\
\hline \multirow[t]{15}{*}{ New Zealand 3472} & Netherlands 15,508 & Ukraine 1727 & Taiwan 14,809 & & \\
\hline & Sweden 9473 & Serbia 1269* & Singapore 4543 & & \\
\hline & Poland 7564 & Croatia 1289* & Thailand 2304* & & \\
\hline & Belgium 7484 & & Malaysia 2092* & & \\
\hline & Denmark 6071 & & Pakistan 1268* & & \\
\hline & Austria 5103 & & & & AFRICA \\
\hline & Finland 4878 & & & & \\
\hline & Portugal 4621* & & & & S'th Africa 3125 \\
\hline & Greece 4534 & & & & Egypt 2515 \\
\hline & Czech Rep. 4127 & & & & Tunisia $1016^{*}$ \\
\hline & Ireland 3186 & & & & \\
\hline & Hungary 2289 & & & & \\
\hline & Romania $1626^{*}$ & & & & \\
\hline & Slovenia 1239* & & & & \\
\hline & Slovakia 1099 & & & & \\
\hline
\end{tabular}

* = countries that have entered the one thousand papers group since 1995

Source: Adapted from NSF, 2014 
Table 3. Top ten school systems in learning achievement of 15-year olds, mean student scores in the three PISA disciplines, compared to UK, USA, Australia, 2012

\begin{tabular}{lll}
\hline \multicolumn{1}{c}{ Reading } & \multicolumn{1}{c}{ Mathematics } & \multicolumn{1}{c}{ Science } \\
\hline Shanghai China 570 & Shanghai China 613 & \\
Hong Kong SAR 545 & Singapore 573 & Shanghai China 580 \\
Singapore 542 & Hong Kong SAR 561 & Hong Kong SAR 555 \\
Japan 538 & Taiwan 560 & Singapore 551 \\
South Korea 536 & South Korea 554 & Japan 547 \\
Finland 524 & Macau SAR 538 & Finland 545 \\
Taiwan 523 & Japan 536 & Estonia 541 \\
Canada 523 & Liechtenstein 535 & South Korea 538 \\
Ireland 523 & Switzerland 531 & Vietnam 528 \\
Poland 518 & Netherlands 523 & Poland 526 \\
& & Liechtenstein 525 \\
& & Canada 525 \\
\hline Australia 504 & Australia 514 & \\
USA 498 & USA 481 & Australia 521 \\
UK 499 & UK 494 & USA 497 \\
& & UK 514 \\
\hline Post-Confucian systems & \\
\hline
\end{tabular}

Post-Confucian systems shaded in grey

Source: Adapted from OECD, 2014 
Table 4. Thirty leading research universities in Asia-Pacific, on the basis of number of science papers in 2009-2012 in the top 10 per cent of the research field on citation rate

\begin{tabular}{|c|c|c|c|c|}
\hline University & $\begin{array}{l}\text { Total } \\
\text { journal } \\
\text { papers } \\
2009-12\end{array}$ & $\begin{array}{c}\text { Proportion } \\
\text { of papers in } \\
\text { top } 10 \% \text { by } \\
\text { citation } \\
\% \\
\end{array}$ & $\begin{array}{l}\text { Number of } \\
\text { papers in } \\
\text { top } 10 \% \text { by } \\
\text { citation }\end{array}$ & $\begin{array}{l}\text { World rank } \\
\text { on number } \\
\text { of papers in } \\
\text { top } 10 \%\end{array}$ \\
\hline Harvard U USA & 29,623 & 23.0 & 6818 & 1 \\
\hline U of Cambridge UK & 11,778 & 18.4 & 2163 & 9 \\
\hline U Tokyo JAPAN & 14,339 & 9.7 & 1389 & 29 \\
\hline National U of Singapore SINGAPORE & 10,387 & 13.1 & 1361 & 30 \\
\hline U Melbourne AUSTRALIA & 9392 & 12.8 & 1198 & 39 \\
\hline U Queensland AUSTRALIA & 8673 & 12.6 & 1089 & 45 \\
\hline U Sydney AUSTRALIA & 9720 & 10.9 & 1056 & 46 \\
\hline Tsinghua U CHINA & 9713 & 10.6 & 1025 & 49 \\
\hline Zhejiang U CHINA & 12,342 & 8.3 & 1018 & 53 \\
\hline Nanyang U Technology SINGAPORE & 7331 & 13.5 & 986 & 55 \\
\hline Kyoto U JAPAN & 11,358 & 8.6 & 982 & 57 \\
\hline Peking U CHINA & 9534 & 9.5 & 906 & 67 \\
\hline Seoul National U KOREA & 12,114 & 7.4 & 901 & 70 \\
\hline Monash U AUSTRALIA & 7172 & 12.4 & 890 & 71 \\
\hline Shanghai Jiao Tong U CHINA & 11,164 & 7.9 & 887 & 72 \\
\hline U New South Wales AUSTRALIA & 7369 & 11.6 & 852 & 78 \\
\hline Fudan U CHINA & 8183 & 9.6 & 784 & 87 \\
\hline Osaka U JAPAN & 9001 & 8.0 & 724 & 95 \\
\hline National Taiwan U TAIWAN & 9226 & 7.5 & 695 & 100 \\
\hline U Hong Kong HONG KONG SAR & 5930 & 11.3 & 669 & 103 \\
\hline U Science and Technology CHINA & 5458 & 11.4 & 621 & 117 \\
\hline Tohoku U JAPAN & 8980 & 6.8 & 606 & 120 \\
\hline Nanjing U CHINA & 6502 & 9.1 & 595 & 123 \\
\hline Australian National U AUSTRALIA & 4385 & 13.3 & 582 & 126 \\
\hline Sun Yat-Sen U CHINA & 6725 & 8.4 & 563 & 130 \\
\hline Chinese U of Hong Kong HONG KONG SAR & 5172 & 10.6 & 548 & 135 \\
\hline Sichuan U CHINA & 7445 & 7.1 & 529 & 145 \\
\hline Harbin Institute of Technology CHINA & 6047 & 8.6 & 522 & 152 \\
\hline Yonsei U STH KOREA & 7598 & 6.7 & 517 & 157 \\
\hline Korea Advanced Institute of S\&T STH KOREA & 4791 & 10.3 & 493 & 169 \\
\hline Jilin U CHINA & 5802 & 8.4 & 466 & 180 \\
\hline Huazhong U S\&T CHINA & 6312 & 7.3 & 463 & 182 \\
\hline
\end{tabular}


Table 5. Comparison of Post-Confucian and English language country systems

\begin{tabular}{|c|c|c|c|}
\hline & $\begin{array}{l}\text { Post-Confucian systems } \\
\text { (East Asia \& Singapore) }\end{array}$ & United States' system & $\begin{array}{l}\text { Westminster systems } \\
\text { (UK, Australia, NZ) }\end{array}$ \\
\hline $\begin{array}{l}\text { Character of } \\
\text { nation-state }\end{array}$ & $\begin{array}{l}\text { Comprehensive, central, } \\
\text { delegates to provinces. Politics } \\
\text { in command of economy and } \\
\text { civil society. State draws best } \\
\text { graduates }\end{array}$ & $\begin{array}{l}\text { Limited, division of } \\
\text { powers, separate from civil } \\
\text { society and economy. Anti- } \\
\text { statism common. Federal }\end{array}$ & $\begin{array}{l}\text { Limited, division of } \\
\text { powers, separate from civil } \\
\text { society and economy. } \\
\text { Some anti-statism. Unitary }\end{array}$ \\
\hline $\begin{array}{l}\text { Educational } \\
\text { culture }\end{array}$ & $\begin{array}{l}\text { Confucian commitment to self- } \\
\text { cultivation via learning. } \\
\text { Education as filial duty and } \\
\text { producer of status via exam } \\
\text { competition (and producer of } \\
\text { global competitiveness) }\end{array}$ & $\begin{array}{l}\text { Twentieth century } \\
\text { meritocratic and } \\
\text { competitive ideology. } \\
\text { Education common road to } \\
\text { wealth/status, within } \\
\text { advancing prosperity }\end{array}$ & $\begin{array}{l}\text { Post } 1945 \text { ideology of state } \\
\text { guaranteed equal } \\
\text { opportunity through } \\
\text { education as path to } \\
\text { wealth and status, open to } \\
\text { all in society }\end{array}$ \\
\hline $\begin{array}{l}\text { State role in } \\
\text { higher } \\
\text { education }\end{array}$ & $\begin{array}{l}\text { Big. State supervises, shapes, } \\
\text { drives and selectively funds } \\
\text { institutions. Over time } \\
\text { increased delegation to part- } \\
\text { controlled presidents }\end{array}$ & $\begin{array}{l}\text { Smaller, from distance. } \\
\text { Fosters market ranking via } \\
\text { research, student loans. } \\
\text { Then steps back. } \\
\text { Autonomous presidents }\end{array}$ & $\begin{array}{l}\text { From distance. Policy, } \\
\text { regulation, funding } \\
\text { supervise market, shape } \\
\text { activity. Autonomous vice- } \\
\text { chancellors }\end{array}$ \\
\hline $\begin{array}{l}\text { Financing of } \\
\text { higher } \\
\text { education }\end{array}$ & $\begin{array}{l}\text { State financed infrastructure, } \\
\text { part of tuition (especially early } \\
\text { in model), scholarships, merit } \\
\text { aid. Household funds much } \\
\text { tuition and private tutoring, } \\
\text { even poor families }\end{array}$ & $\begin{array}{l}\text { State funds some } \\
\text { infrastructure, tuition } \\
\text { subsidies, student loans. } \\
\text { Households vary from high } \\
\text { tuition to low, poor } \\
\text { families state dependent }\end{array}$ & $\begin{array}{l}\text { Less state financed } \\
\text { infrastructure now. Tuition } \\
\text { loans, some aid. Growing } \\
\text { household investment but } \\
\text { less than East Asia. } \\
\text { Austerity }\end{array}$ \\
\hline $\begin{array}{l}\text { Dynamics of } \\
\text { research }\end{array}$ & $\begin{array}{l}\text { Part household funding of } \\
\text { tuition, ideology of WCU, } \\
\text { university hierarchy: together } \\
\text { enable rapid state investment in } \\
\text { research at scale. Applied is } \\
\text { dominant. State intervention. }\end{array}$ & $\begin{array}{l}\text { Research heavily funded } \\
\text { by federal government } \\
\text { unburdened by tuition. } \\
\text { Industry and philanthropic } \\
\text { money. Basic science plus } \\
\text { commercial IP. }\end{array}$ & $\begin{array}{l}\text { Research funded (more in } \\
\text { UK) by government, also } \\
\text { finances tuition. Less } \\
\text { philanthropy than US. } \\
\text { Basic science, applied } \\
\text { growth, dreams of IP }\end{array}$ \\
\hline $\begin{array}{l}\text { Hierarchy and } \\
\text { social selection }\end{array}$ & $\begin{array}{l}\text { Steep university hierarchy. } \\
\text { 'One-chance' universal } \\
\text { competition with selection into } \\
\text { prestige institutions. WCUs are } \\
\text { fast track for life }\end{array}$ & $\begin{array}{l}\text { Steep institutional } \\
\text { hierarchy mediated by } \\
\text { SAAT scores. Some part } \\
\text { second chances, mainly } \\
\text { public sector. Top WCUs } \\
\text { are fast track for life }\end{array}$ & $\begin{array}{l}\text { Competition for place in } \\
\text { university hierarchy } \\
\text { mediated by school results } \\
\text { with some part second } \\
\text { chances. WCUs provide } \\
\text { strong start }\end{array}$ \\
\hline $\begin{array}{l}\text { Fostering of } \\
\text { World-Class } \\
\text { Universities }\end{array}$ & $\begin{array}{l}\text { Part of tradition, universal } \\
\text { target of family aspirations. } \\
\text { Support for building of WCUs by } \\
\text { funding and regulation. } \\
\text { Emerging global agenda }\end{array}$ & $\begin{array}{l}\text { Entrenched hierarchy of } \\
\text { Ivy League and flagship } \\
\text { state universities, via } \\
\text { research grants, tuition } \\
\text { hikes, philanthropy. Source } \\
\text { of global pride }\end{array}$ & $\begin{array}{l}\text { Ambivalence in national } \\
\text { temperament and } \\
\text { government policy on } \\
\text { status of top institutions. } \\
\text { Private and public funding } \\
\text { hit ceilings }\end{array}$ \\
\hline
\end{tabular}

Source: author 
Table 6. Joint publication of Australian-authored science, by selected partner countries, 1995 and 2012

$1.00=$ expected rate of collaboration based on overall collaboration patterns of the two countries

\begin{tabular}{lcc}
\hline & $\mathbf{1 9 9 5}$ & $\mathbf{2 0 1 2}$ \\
\hline South Africa & 1.86 & 1.85 \\
UK & 1.05 & 1.24 \\
Ireland & 0.42 & 0.97 \\
Canada & 0.76 & 1.00 \\
United States & 0.80 & 0.76 \\
Germany & 0.52 & 0.72 \\
France & 0.37 & 0.71 \\
Brazil & 0.27 & 0.92 \\
& & \\
\hline
\end{tabular}

\begin{tabular}{lcc}
\hline & $\mathbf{1 9 9 5}$ & $\mathbf{2 0 1 2}$ \\
\hline New Zealand & 4.49 & 3.65 \\
Singapore & 2.01 & 1.48 \\
China & 1.11 & 1.11 \\
India & 0.61 & 0.79 \\
Taiwan & 0.30 & 1.14 \\
Japan & 0.60 & 0.79 \\
South Korea & 0.33 & 0.54 \\
Russia & 0.31 & 0.72 \\
& & \\
\hline
\end{tabular}

Source: NSF, 2014 
Figure 1. Total spending on R\&D, top 10 countries, 2011, USD\$s billion

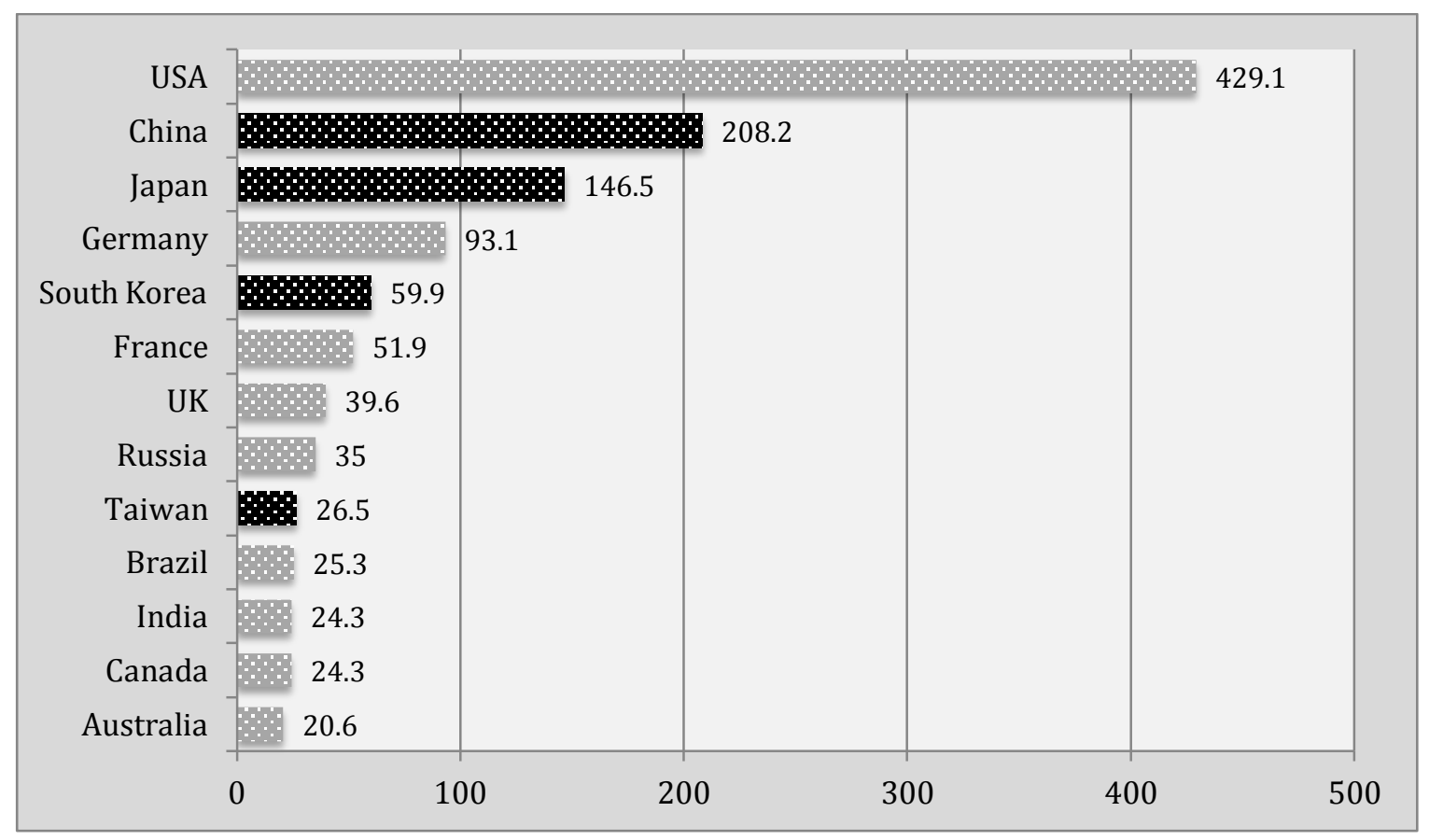

Current USD

Source: NSF, 2014. 
Figure 2. Number of journal papers produced in 2000 and 2011, 14 leading countries

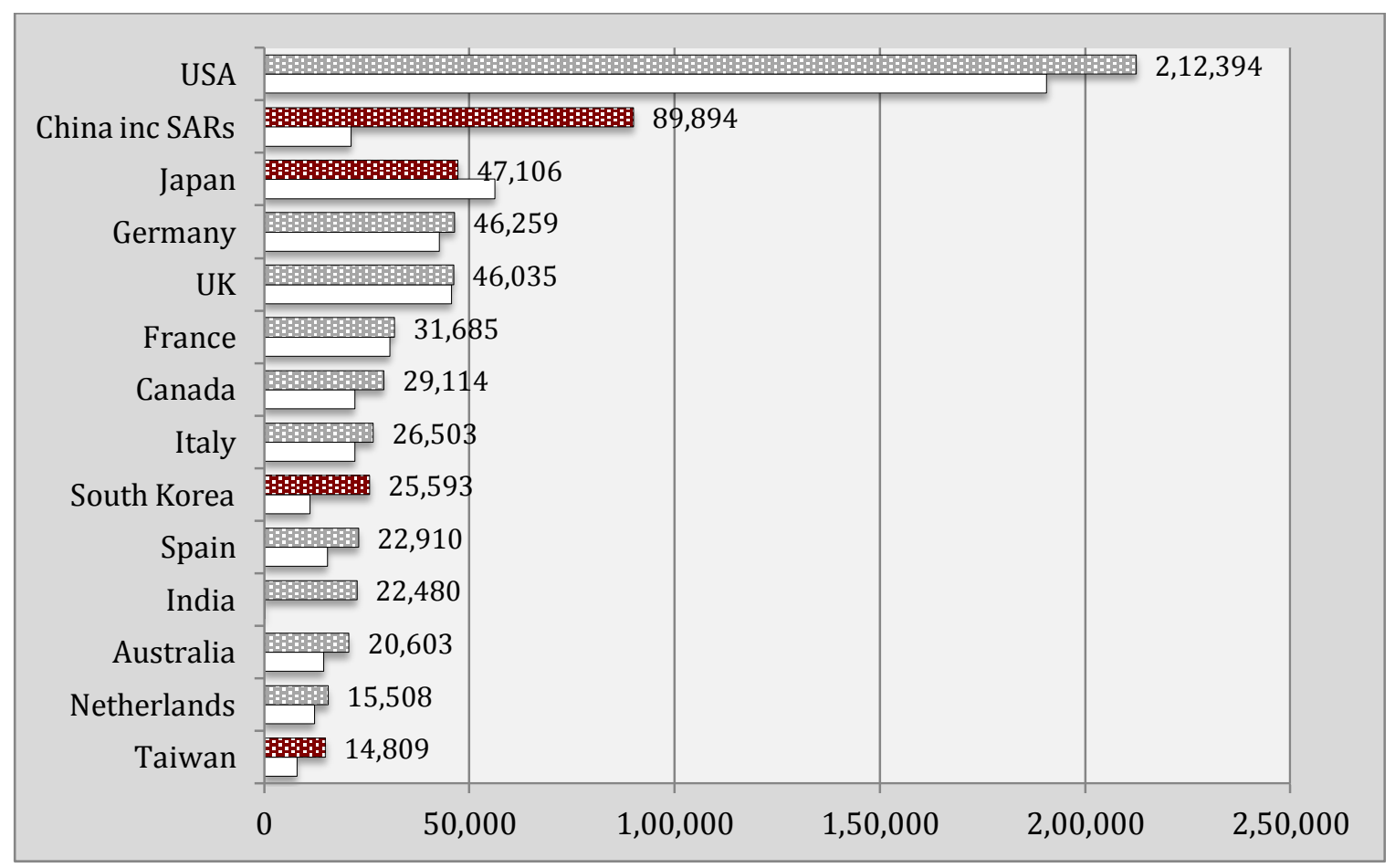

Source: NSF, 2014. 
Figure 3. Output of journal papers in science 1995 to 2011, seven countries

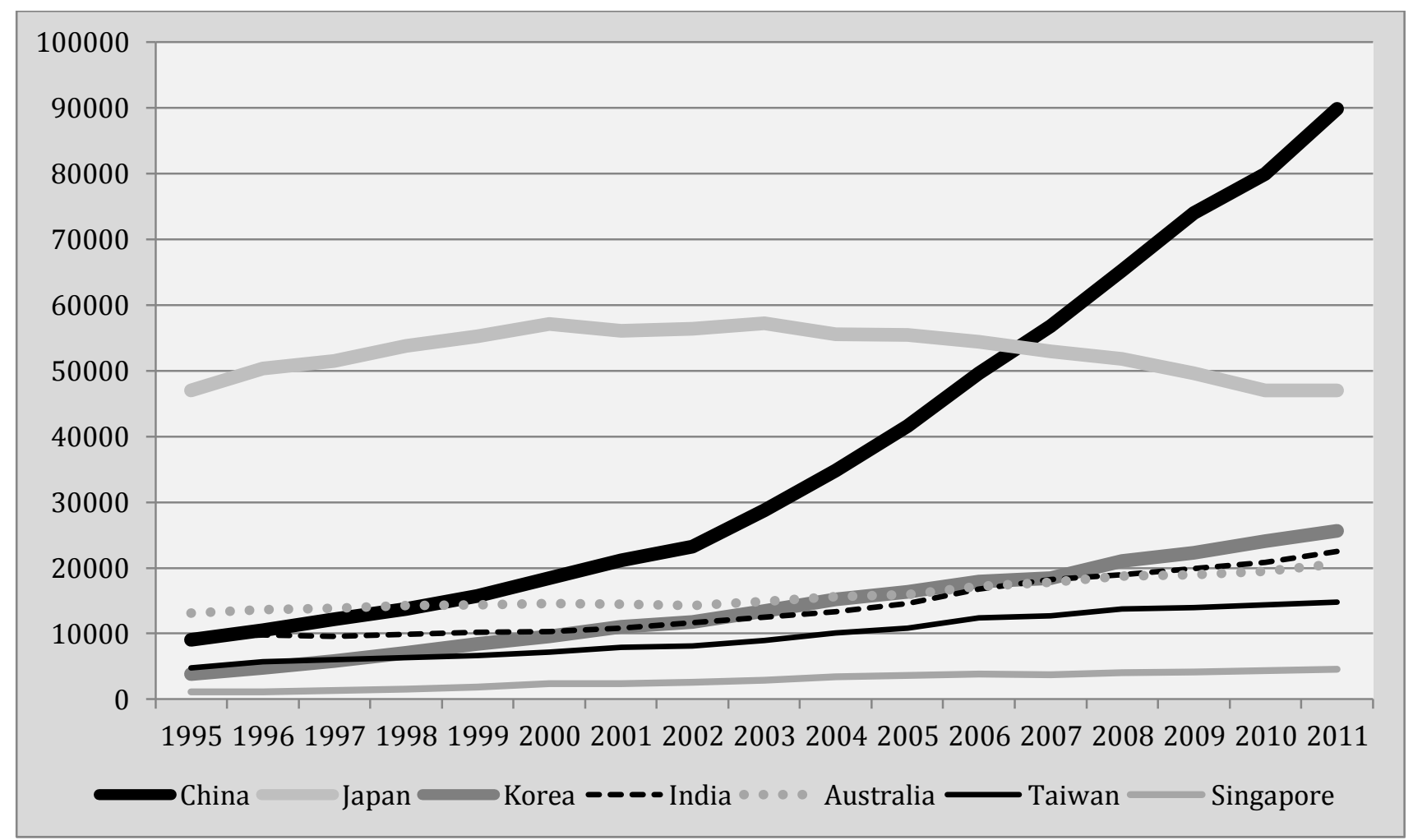

Source: NSF, 2014 


\section{University Library}

\section{- M M N E R VA A gateway to Melbourne's research publications}

Minerva Access is the Institutional Repository of The University of Melbourne

Author/s:

Marginson, S

Title:

The strategic positioning of Australian research universities in the East Asian region

Date:

2015-08-01

Citation:

Marginson, S. (2015). The strategic positioning of Australian research universities in the East Asian region. HIGHER EDUCATION, 70 (2), pp.265-281. https://doi.org/10.1007/ s10734-014-9839-5.

Persistent Link:

http://hdl.handle.net/11343/282595 